Journal of English Language Teaching and Applied Linguistics

ISSN: 2707-756X

DOI: $10.32996 /$ jeltal

Journal Homepage: www.al-kindipublisher.com/index.php/jeltal

\title{
Comparing the Order of Multi-Layered Modifiers in English, Chinese and Vietnamese in Language Teaching
}

\author{
Vo Thi Quynh Trang 8 (iD. \\ Ho Chi Minh City University of Food Industry, Ho Chi Minh City, Vietnam \\ $\triangle$ Corresponding Author: Vo Thi Quynh Trang, E-mail: trangvtq@hufi.edu.vn
}

\begin{tabular}{|c|c|}
\hline ARTICLE INFORMATION & ABSTRACT \\
\hline $\begin{array}{l}\text { Received: May 04, } 2021 \\
\text { Accepted: June 08, } 2021 \\
\text { Volume: } 3 \\
\text { Issue: } 6 \\
\text { DOI: } 10.32996 / \text { jeltal.2021.3.6.9 }\end{array}$ & $\begin{array}{l}\text { From the cross-linguistic perspective and cognitive linguistic theory, this study has } \\
\text { analysed the rules of multi-layered modifiers in English, Chinese, and Vietnamese, } \\
\text { pointing out their common points and differences. Although all three languages } \\
\text { belong to the SVO (subject-verb-object) type but modifiers in English and Chinese are } \\
\text { in front of the core words, which shows that English and Chinese belong to the } \\
\text { language in the left branch, but modifiers in Vietnamese, they are behind the core }\end{array}$ \\
\hline $\begin{array}{l}\text { Multi-layer modifiers, cognitive } \\
\text { linguistics, foreign language } \\
\text { teaching }\end{array}$ & $\begin{array}{l}\text { words which shows that Vietnamese belongs to the right branch. All the three } \\
\text { languages have one thing in common, whether they are on the left or on the right } \\
\text { branch, in which modifiers have the closest relationship with the core words that will } \\
\text { stand nearest to them. Other modifiers that have a non-intimate relationship with the } \\
\text { core words will stand further away from them. Thus, mastering this feature of the } \\
\text { three types of languages will help in language teaching and learning. }\end{array}$ \\
\hline
\end{tabular}

\section{Introduction}

This study stands from a cognitive perspective to study the order rules of multi-layered modifiers of 3 languages. "Multi-layered modifier" is a noun that has several components to modify simultaneously, including nouns, adjectives, words of number, etc. The focus of this study is to highlight the similarities and differences of the multi-layered modifier order of these three languages.

\section{The linguistic view and theoretical basis of cognitive linguistics}

Cognitive linguistics is a new school of linguistics in the 1990s. It widely absorbs other sciences such as cognitive science, linguistics, psychology, neuroscience, philosophy, and anthropology. Analytical methods and research results of cognitive linguistics have challenged and completely new perspectives to the traditional linguistic theory.

According to its definition, cognitive linguistics "is a school of linguistics that studies language based on our experience in life and our perception of the world and brings these methods, strategies and conceptualization to serve as the basis for conducting language research". Its philosophical basis is the non-objectivist cognitive view, which opposes the western traditional objectivist paradigm, which holds that the basis of the existence of the reality category is completely independent of the human mind. The human mind only reflects reality passively in the way of reflection. Cognitive linguistics believes that the objectivism cognitive model cannot properly describe human mental activities and language. George Lakoff and Johnson (1978), who are representative for the school, abandoned the form of idealism and objectivism and put forward empiricism and realism, which recognizes the reality of objective existence. It also emphasizes the empiric aspect. Unlike the old empiricism, this new empiricism holds that there is neither absolute objective reality nor independent perception and thinking without objective reality, but only the opposite cognition and experience in a certain environment (natural environment and social and cultural environment). There is no direct connection between objective reality and human language. The conceptual system and various concepts are produced by the human brain's cognition of the objective world under the promotion of human experience.

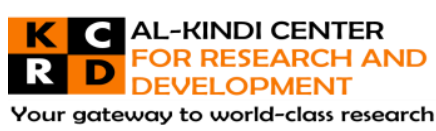

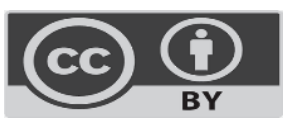

Published by Al-Kindi Center for Research and Development, United Kingdom. Copyright (c) the author(s). This open access article is distributed under a Creative Commons Attribution (CC-BY) 4.0 license 
Cognitive linguistics is a new school of linguistics in the 1990s. It widely absorbs other sciences such as cognitive science, linguistics, psychology, neuroscience, philosophy, and anthropology. Analytical methods and research results of cognitive linguistics have put forward challenging and completely new perspectives to the traditional linguistic theory.

Cognitive linguistics holds a functionalist linguistic view. Its basic propositions are as follows: (1) natural language does not directly reflect the objective world but is the product of human cognitive activities. It is also a tool to consolidate and record cognitive achievements. Its structure and function should be regarded as the result and reflection of human general cognitive activities (2) Natural language is the symbolic expression of conceptualized reality. The meaning of language is rooted in the cognition of interaction between human and the objective world and in the user's understanding and belief of the world. Therefore, semantic knowledge and pragmatic knowledge are inseparable; (3) Semantic structure focuses on language research. The semantic structure does not directly correspond to the structure of the objective external world but to the cognitive structure; that is, it corresponds to the conceptual structure closely related to human body experience, cognitive strategies and cultural conventions formed in the process of interaction with the objective reality; (4) The surface syntactic structure directly corresponds to the semantic structure, and different forms of syntax come from and reflect different semantics. To a certain extent, syntactic structure is not arbitrary and autonomous but has a natural motivation; its external form is often driven by factors other than cognition, function, and pragmatics. In a word, cognitive linguistics studies the organization principles of language from the perspective of cognition. Therefore, it has two-way goals: to explain grammatical phenomena with people's cognitive psychological characteristics and the complex grammatical phenomenon behind the excavation of their cognitive basis. Linguist Ferdinand de Saussure (1857-1913) in his classic work "Course in General linguistics," argued that "randomity" is one of the basic characteristics of the language. The relationship between "signifier" and "signified" is arbitrary. The signs that are spoken are a combination of "signifier" and "signified", so to put it simply, the linguistic sign is arbitrary. He further explained that arbitrariness means that there is "no natural connection" between the signifier and the signified, and the combination of the two is "irrefutable" or "groundless". However, while recognizing the arbitrariness of language, cognitive linguistics emphasizes the non-arbitrariness of language, mainly because the structure of language, especially the grammatical structure, is nonarbitrariness, justifiable and arguably has a natural connection with the structure of human experience. This is the iconicity of language, which is a core theory of cognitive linguistics.

\section{Rules of the order of Chinese, English and Vietnamese}

Among the three languages, Chinese, English, and Vietnamese, English belongs to the type of fusion language, and Chinese and Vietnamese belong to the type of monolingual language, but all three share the same phenomenon: multi-layered modifiers. Floor. Many Chinese and English grammar books, when discussing the order of multi-layered modifiers, all think that this order is fixed in which they often go in front of the core words, while in Vietnamese, the position of the modifiers is very flexible, they can come before or after the core words. In the following, the article will give some example sentences to compare and contrast the multi-layered modifier order of these three languages.

Ex1:

English: a beautiful purple silk scarf

$$
\text { (4) (3) (2) (1) }
$$

The English multi-layered modifier order: (4)determiner-- (3)opinion -- (2)color -- (1)material Core word

Chinese: 二 $\underset{\text { (4) }}{\text { 条 }}$ (5) 漂亮的紫色的真丝围巾

The Chinese multi-layered modifier order: (4)determiner-- (5) quantifier (3)opinion--(2)color-- (1)material-- Core word

Vietnamese: môt chiếc khăn quàng lua tím $\frac{\text { xinh đep }}{(4)}$

The Vietnamese multi-layered modifier order: (4)determiner-- (5)quantifier -- Core word--(1)material -- (2)color -- (3)opinion Ex2:

English: two new sport bikes

$$
\text { (3) (2) (1) }
$$

The English multi-layered modifier order: (3number-- (2)age -- (1)qualifier -- Core word

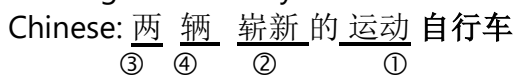

The Chinese multi-layered modifier order: (3)number-- @4quantifier -- (2)age -- (1)qualifier -- Core word

Vietnamese: hai chiếc xe đạp thể thao mới

$$
\text { (3) (4) (1) (2) }
$$

The Vietnamese multi-layered modifier order: (3)number -- (4quantifier -- Core word --(1)qualifier -- (2)age

Ex3:

English: $\underline{m y}$ expensive new big green bag 
(5) (3) (2) (1)

The English multi-layered modifier order: (5)determiner (4)opinion -- (3)age-- (2)size -- (1)color -- Core word

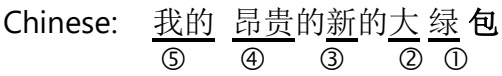

The Chinese multi-layered modifier order: (5)determiner -- (4)opinion-- (3)age-- (2)size -- (1)color -- Core word

Vietnamese: cái túi xanh lớn mới đắt tiền của tôi

$$
\text { (1) (2) (3) (4) (5) }
$$

The Vietnamese multi-layered modifier order: Core word -- (1) color -- (2)size -- (3)age-- (4)opinion-- (5)determiner Ex4:

English: six beautiful old wooden houses

$$
\text { (4) (3) (2) (1) }
$$

The English multi-layered modifier order: (4)number -- (3)opinion-- (2)age -- (1)material -- Core word

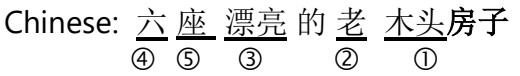

The Chinese multi-layered modifier order: (5)number-- (4) quantifier -- (3)opinion -- (2)age-- (1)material -- Core word

Vietnamese: $\frac{\text { sáu }}{\text { (4) (5) }}$ nqôi nhà qỗ $\frac{\text { cũ kỹ }}{\text { (2) }} \frac{\text { inh đep }}{\text { (3) }}$

The Vietnamese multi-layered modifier order: (4)number-- (5)quantifier -- Core word -- (1)material -- (2)age -- (3)opinion Ex5:

English: Her moving love song

(3) (2) (1)

The English multi-layered modifier order: (3)determiner -- (2)opinion-- (1)qualifier -- Core word

Chinese :她的动人的爱情歌曲

$$
\text { (3) (2) (1) }
$$

-The Chinese multi-layered modifier order: (3)determiner -- (2)opinion-- (1)qualifier-- Core word

Vietnamese: bài hát tình yêu cảm đông của cô ấy

The Vietnamese multi-layered modifier order: Core word -- (1)qualifier-- (2)opinion -- (3) determiner

Ex6:

English: Anny's five old little plastic rulers

$$
\text { (5) (4) (3) (2) (1) }
$$

The English multi-layered modifier order:(5)determiner-- (4)number-- (3)age-- (2)size-- (1)material -- Core word

Chinese: 安妮的五条㫜的 小塑料尺子

$$
\text { (6) (4) (5) (3) (2) (1) }
$$

The Chinese multi-layered modifier order: (6)determiner -- (4)number -- (5)quantifier-- (3)age --(2)size -- (1)material--Core word Vietnamese: năm cây thước nhưa nhỏ cũ của Anny

$$
\text { (4) (5) (1) (2) (3) (6) }
$$

The Vietnamese multi-layered modifier order: (4)number--(5)quantifier--Core word--material--(2)size-- (3)age -- (6)determiner Ex7:

English: all the six pretty young Australian women athletes

$$
\text { (7) (6) (5) (4) (3) (2) (1) }
$$

The English multi-layered modifier order: (7)quantifier--(6)determiner-- (5number--(4)opinion--(3)--(2)nationality-(1) qualifier-- Core word

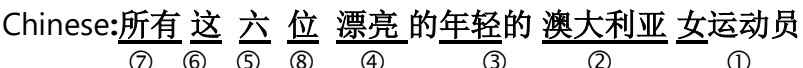

The Chinese multi-layered modifier order: (7)quantifier-- (6)determiner--(5)number--(8)quantifier--(4)opinion--(3)age--(2) nationality-- (1)qualifier-- Core word

Vietnamese: tất cả sáu vi vận động viên nữ nqười Úc trẻ trung xinh đep này

$$
\text { (7) (5) (8) (1) (2) (3) (4) (6) }
$$

The Vietnamese multi-layered modifier order: (7)quantifier--(5)number--(8)quantifier--Core word-- (1)qualifier -- (2)nationality -(3)age-- (4)opinion--(6)determiner

From the above examples, it shows that English and Chinese have a multi-layered modifier order that always precedes the core word, while in Vietnamese has a very flexible multi-layered modifier order. They can come before and after the core word.

The general order of English and Chinese is a possessive word--indicative/article-- number, quantifiers (English has no quantifiers) ----descriptive adjectives (state)-- -attribute adjectives (new and old, big and small, shape, age, color, etc.)--noun (material, function)-- Core word. 
The order of Vietnamese is: indicative word--number -- quantifier-- Cord word-- noun (material, function)--attributive adjective (new, old, big, small, shape, age, color, etc.) --descriptive adjective(state)

\section{Chinese and English}

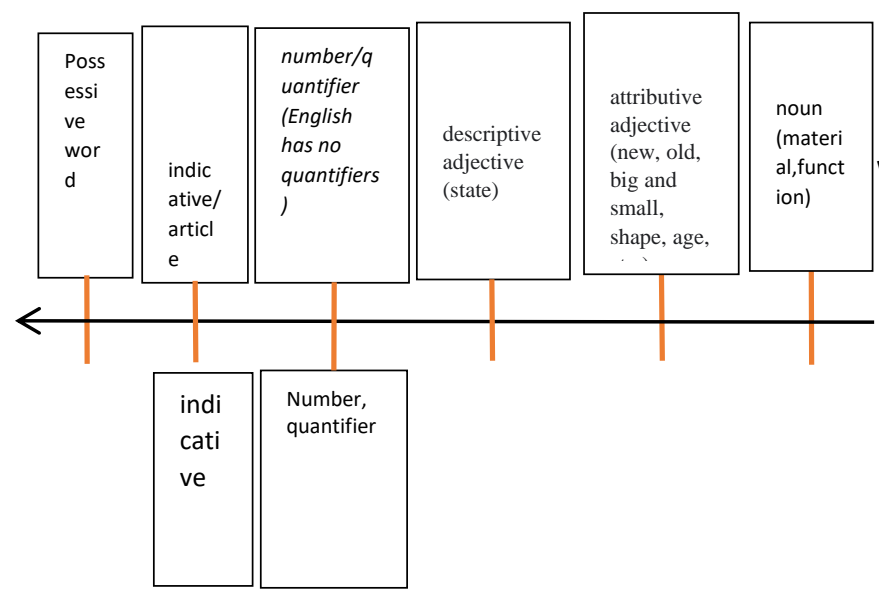

Table of multi-layered modifiers in the three languages

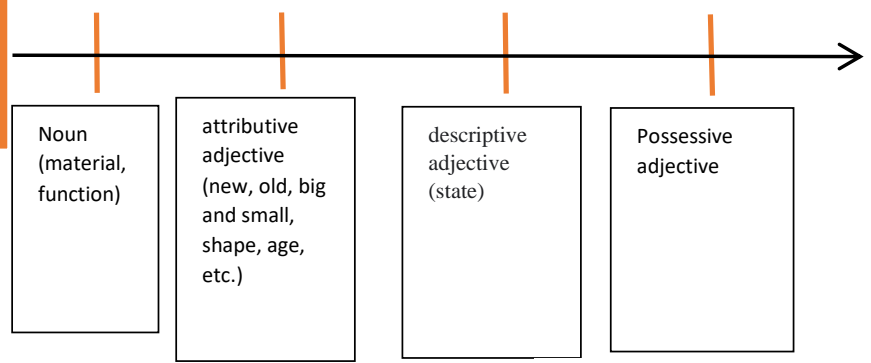

Vietnamese

\section{Results and Discussion}

From a cognitive perspective, observe the order of multi-layered modifiers of the three languages. The above order is shown by the same principle of cognitive linguistics, even though English and Chinese multi-layered modifiers are similar. English follows the left branch, while Vietnamese mostly follows the right branch but still adheres to the principle: the distance between the expressed concepts determines the distance between the core word and the modifier. The closer the meaningful relationship is between the core word and the modifier; the shorter distance is between them. The formal relation reflects the meaningful relationship.

In addition, there are a few examples because there is a change in the order of modifiers which leads to a change in the meaning of the sentence

Ex 8:

English: good chocolate milk

Chinese: 好吃巧克力牛奶

Vietnamese: sữa cô sô la ngon

Ex 9:

English: good milk chocolate

Chinese: 好吃牛奶巧克力

Vietnamese: sô cô la sữa ngon

It can be seen that the closet component to the center determines the content (nature) of the core word. The two examples above reflect the unity of the modifying order. In addition, some adjectives do not modify the core word at all but modify the right adjective.

Ex 10:

English: an extra strong box

Chinese:一个很结实的盒子

Vietnamese: một cái hộp rất cứng

Ex 11:

English : in extreme old age

Chinese: 很老的年龄

Vietnamese : độ tuổi rất già

Ex 12:

English: extra fine quality

Chinese: 特别好的质量

Vietnamese: chất lượng đặc biệt tốt 
It can be seen that, in English, Chinese and Vietnamese, if an adverb adds meaning to an adjective, its distance from the core word will be farther than the distance of the adjective from the core word.

In addition to the above case, in reality, there are many different causes. Let us compare the example below:

Ex 13:

English: a best friend of my sister's

Chinese: 我姐姐的一个好朋友

Vietnamese: một người bạn tốt của chị gái tôi

Compare with

Ex14:

Chinese :我姐姐的好朋友

English :my sister's good friend = a good friend of my sister

Vietnamese: người bạn tốt của chị gái tôi

It can be seen that, in Chinese, the possessive word seems to precede quantifiers. In Vietnamese, it comes after quantifiers, but in English, if the definite expression indicates the whole, the possessive word can be brought out. Before, can also use the possessive form of in the back; but if expressing a whole indefinite concept, for example, "My sister have some close friends", the possessive word must be in the back, and the possessive forms "'s" and "of" are used. ". Similar examples include:

Ex 15:

Chinese:汤姆的那三本书 (Tom's books are not only three books.)

English :the three books of Tom's

Vietnamese: ba quyển sách kia của Tom

Ex16

Chinese: 我的那条真丝围巾(My silk scarf is not just one.)

English: that silk scarf of mine

Vietnamese: chiếc khăn quàng lụa thật của tôi đó

Ex17:

Chinese:你姐姐的这个可爱的孩子(Your sister's child is not the only one.)

English:this lovely child of your sister's

Vietnamese:Đứa con đáng yêu của chị gái bạn đây

\section{Conclusion}

The research has analyzed many examples of multi-layered modifiers of English, Chinese and Vietnamese. It identified the similarities and differences among them, and found the rules of multi-layered modifier order of the three languages:

1. The order of multi-layered modifiers in English and Chinese:

Possessive word--indicator/article-- number, quantifier (English has no quantifier), descriptive adjective(state), attribute adjective (new, old, big, small, shape, age, color...), noun (material, function) and core word.

2. The order of multi-layered modifiers in Chinese:

Possessive word--indicator/article-- number, quantifier----descriptive adjective(status)--attribute adjective (new-old, big, small, shape, age, color...) --noun (material, function) and core word.

3. The order of multi-layered modifiers in Vietnamese:

The order of Vietnamese is: indicator--number-- quantifier--core word-- noun (material, function) --attributive adjective (new and old, big and small, shape, age, etc.) --descriptive adjective(state)

From a cognitive perspective, the multi-layered modifier order of English and Chinese is basically similar, while the multi-layered modifier order of Vietnamese compared to English and Chinese has differences as well as similarities. Three multi-layered modifier rules of the three above languages make us realize and understand the commonality of the languages more deeply. Different peoples perceive the same worldview and have similar psychological and emotional reactions. Physiological structures seem to be similar using different languages to express similar experiences and basic perceptions. The commonality of language has shown the universality and commonality of cognitive objects, cognitive strategies, and human cognitive capacity, which have great significance for translation and cross-cultural exchange, especially in foreign language teaching and learning.

In English, Chinese and Vietnamese teaching, the grammar point of multi-layered modifiers is always an important one, if learners do not master the multi-layered modifier grammar rules, mistakes will easily arise. This study hopes to contribute to helping teachers and learners improve their understanding of teaching and learning. 
Future research could expand the scope by studying the multi-layered modifier order of Japanese, Korean, and Thai because they are languages heavily influenced by Chinese. Also, future research could study the influencing factors affecting the multilayered modifier order of languages.

\section{References}

[1] 张敏,(1998), 认识语言学与汉语名词短信, 北京:中国社会科学出版社

[2] Johnson,M.(1987).The Body in the Mind :The Bodily Basis of Meaning,Imagination, and Reason.Chieago:University of Chicago Press

[3] Lakoff,George.(1987).Women,Fire, and Dangerous Things:What Categories Reveal about the Mind.Chicago \& London:The University of Chicago Press

[4] 潘文国,(2003), 汉英语对比纲要,北京语言文化大学出版社

[5]陈定安,(1991), 英汉比较与翻译,中国对外翻译出版公司,香港:商务印书馆〔香港)有限公司

[6] 杨自俭,(2002)，英汉语比较与翻译，上海:上海外语教育出版社 